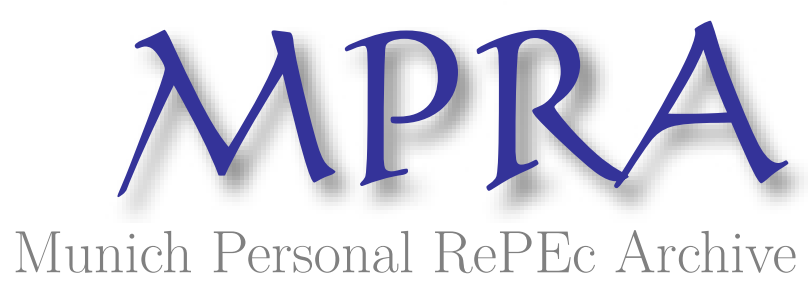

\title{
How Do Female Spouses' Political Interests Affect Male Spouses' Views About a Women's Issue?
}

yamamura, Eiji

24 April 2009

Online at https://mpra.ub.uni-muenchen.de/14837/

MPRA Paper No. 14837, posted 25 Apr 2009 02:15 UTC 


\title{
How Do Female Spouses' Political Interests Affect Male Spouses' Views About a Women's Issue?
}

\begin{abstract}
This paper explored how the degree of female spouses' political interest affects male spouses' views about women's empowerment, using individual level data in Japan. Controlling for unobserved city size and area-specific fixed effects, results showed that males were likely to consider women's empowerment important if their spouses were interested in politics. This spouse effect was observed for conservative males but not for progressive ones. Results were unchanged when the endogeneity bias caused by spouses' political interests were controlled for. These findings suggest that female family members' political interests and views play an important role in determining male views regarding women's issues.
\end{abstract}

Keywords: Spouse, political opinion, women's empowerment JEL classification: D72, D83, J12, J16 


\section{Introduction}

How and why is an individual's preference influenced by the environment? A growing amount of research has examined this question. Some studies have explored the influence of fathers, mothers, and siblings on a family member's decision making (e.g., Bertrand et al., 2000; Fernandez et al., 2004; Kawaguchi \& Miyazaki, 2009; Sacerdote, 2007). ${ }^{1}$ In addition, gender gaps in views about political issues have been increasingly observed (Goldin, 1990).2 For instance, it has been found that females are more likely than males to consider growth in social welfare spending important (Funk \& Athmann, 2008) and to support left-wing policies (Edlund \& Pande, 2002). ${ }^{3}$

These findings prompt the following question: How is an individual's political view affected by the gender of family members or spouses? ${ }^{4}$ Previous studies have provided evidence that offspring gender has a critical influence on parents' views about gender (e.g., Warner, 1991; Warner \& Steel, 1999; Washington, 2008). ${ }^{5}$ Edlund and Pande (2002) have suggested that the gender gap in political views decreases following marriage, whereas the gap increases following divorce. Intuition suggests that the extent of influence of opposite sex family members would depend on their political interest. That is, the degree of a wife's or daughter's political interest would be associated with the husband's or father's political view. In this case, the husband's or father's general political position should also be considered. However, the relationship between a husband's and wife's characteristics in relation to political views has not been sufficiently taken into account when male political views have been analyzed. To examine this issue, using individual level data in Japan, this paper investigated the effect spousal political interest had on male views about women's empowerment. Furthermore, this effect was compared in conservative and progressive males.

\footnotetext{
${ }^{1}$ In the area of public choice, family is treated as a decision-making unit with intergenerational transfer when a voting model is constructed (Breyer \& von der Schulenburg, 1990).

2 Cebula and Meads (2008) have researched the determinants of gender difference related to voter turnout.

3 According to historical works, it is acknowledged that women's suffrage has had a critical influence on size of government and the allocation of public spending (e.g., Abrams \& Settle, 1998; Aidt \& Dallal, 2008; Lott \& Kenny, 1999; Miller, 2008).

4 Wolfinger and Rosenstone (1980) have asserted that married people are more likely to vote than single people.

5 Washington (2008) has reported that men with daughters tend to support policies giving benefits to females, implying that fathers' political views are affected by their daughters.
} 


\section{Methods}

2.1. Data

This paper used individual level data including demographic characteristics (age and sex), household income, education, and political position. ${ }^{6}$ In addition, spouse's political interest was also considered. Data was constructed from the Japanese Election and Democracy Study 2000 survey (JEDS hereafter) conducted in all parts of Japan in 2001. A total of 2500 adults (aged 20 years or older) were invited to participate in a survey with stratified two-stage random sampling. The survey collected data on 1618 adults, resulting in a response rate of $64.7 \%$. There were 180 sample points divided into 11 areas. According to population size, cities and towns were divided into 5 groups including 13 metropolitan cities, cities with at least 200,000 people, cities with at least 100,000 people, and other cities, towns and villages.

The construction of samples used in this research is shown in Table 1. The original sample contained 1618 observations; 749 were males. Sample size was reduced to 478 when some observations were deleted due to missing values for views about women's empowerment and respondents' characteristics such as age, household income, education or marital status. Furthermore, after excluding observations without valid answers for spouse's political interest, the sample size became 419. The remaining observations divided into progressive and conservative males were 239 and 180, respectively. These observations were used for the probit estimation, and results are shown in Table 3. To control for endogeneity bias caused by spouse's political interest, I restricted the sample to males with spouses whose ages were available because spouse's age was used as an instrumental variable. This additional selection further reduced the samples. ${ }^{7}$ Results using these samples are reported in Table 4.

Variables used for estimation are as follows. The dependent variable was whether respondents thought women empowerment important, measured using the question "In the list, please choose all that you think are important." Respondents could choose

6 The data for this secondary analysis was from the "Japanese Election and Democracy Study 2000 Survey: Social Capital and Perception of Democracy in Japan." This data was designed and carried out in 2000 by the JEDS research group (Yoshitaka Nishizawa, Hiroshi Hirano, Ken'ichi Ikeda, Ichiro Miyake, and Aiji Tanaka). Data were provided by the Social Science Japan Data Archive, Information Center for Social Science Research on Japan, Institute of Social Science, The University of Tokyo.

7 It should be noted that selection bias occurred due to restricting samples to males with spouses. Controlling for both endogeneity bias and sample selection bias should be required and is a remaining issue in future research. 
numbered statements from among the list, which included "women empowerment in public affairs." by the question "Is your spouse interested in politics?" Response choices were "interested" or "not interested." Control variables were males' ages, household incomes, and years of education.

Women's empowerment was presumed to be important for females but not for males. Therefore, we anticipated that male views about women's empowerment would be influenced by spouses. A cursory examination of Figure 1(a) reveals that males with spouses were more likely to think women's empowerment important than males without spouses, implying that male views about women's issues appear to depend on the presence of a spouse. This finding is consistent with previous works (e.g., Warner, 1991; Warner \& Steel, 1999; Washington, 2008). Further restricting the sample to males with spouses, shown in Figure 1(b), revealed that males with spouses interested in politics were 1.5 times more inclined to think women's empowerment important than males with spouses not interested in politics. It can be concluded from Figure 1(a) and (b) that males seem to be influenced not only by family structure but by a family member's attitude towards politics.

Table 2 presents means of variables for progressive and conservative male groups. ${ }^{9}$ Consistent with intuitive thought, the percentage of respondents who considered women empowerment important was higher in the progressive group than in the conservative group, $24.4 \%$ and $18.5 \%$, respectively. The percentage of spouses interested in politics in the progressive group (22.5\%) was slightly higher than in the conservative group (21.3\%). This suggests that progressive males are more inclined to choose more political females as spouses. ${ }^{10}$ The progressive group was younger, had lower household incomes, and was more educated than the conservative group.

\subsection{Analyses}

I explored how the degree of a spouse's political interest affected a male's political opinion about women's empowerment. The estimated function takes the following form:

\footnotetext{
8 The list contained 10 choices. Excluding women's empowerment, choices were not associated with gender issues.

9 Male political position was measured by the question "If progressive is "0" and conservative is "10," what do you think might best indicate your own position?" Responses ranged from 0 (progressive) to 10 (conservative). Males who chose 0 to 5 and males who chose 6 to 10 were considered progressive and conservative, respectively. 10 It seems appropriate to conjecture that a male's political position has an influence on his spouse's political interest. This effect appears to result in estimation bias and should be controlled for in future studies.
} 
Women's empowerment imn $=\alpha_{0}+\alpha_{1}$ (Spouse dummy) ${ }_{\text {imn }}+\alpha_{2}$ (Spouse dummy)* (interest in politics dummy) imn $+\alpha_{3}$ Ln (age) imn $+\alpha_{4} L n$ (household income) ${ }_{i m n}+\alpha_{5} L n$ (years of education) ${ }_{i m n}+e_{m}+f_{n}+u_{i m n}$,

where Women's empowerment imn represents the dependent variable in individual $i$, city size $m$, and area $n$. Regression parameters are symbolized by $\alpha$ s. Unobservable city size and area specific effects are represented by $e_{m}$ and $f_{n}$, which are controlled by dummy variables, and uimn represents the error term. The empirical model was estimated using Probit analysis. The dependent variable, Women's empowerment, was coded 1 if women's empowerment was thought to be important, otherwise it was 0 . Spouse dummy was 1 if the male had a spouse, otherwise it was 0. As shown in Figure 1(a), a male's view about a women's issue depended on whether he had a spouse. Spouse dummy was expected to take the positive sign. Interest in politics dummy was coded 1 if a spouse was interested in politics, otherwise it was coded 0 . The key variable was the interaction term between Spouse dummy and Interest in politics dummy, which captured how the degree of a spouse's political interest affected the male's political view. As presented in Figure1(b), a male's view about a women's issue was affected by the spouse's political interest; (Spouse dummy)* (interest in politics dummy) was expected to yield the positive sign. In addition, males' ages, household incomes, and years of education were included to control for individual characteristics.

I conducted the estimation using all samples. Then, to compare effects of male's political position, samples were split into progressive and conservative males. Separate estimations were carried out using these split samples. As mentioned earlier in the Data section, a male's political position could seemingly affect choice of females, resulting in endogeneity bias. Therefore, I restricted the sample to males with spouses and used the Probit model with endogenous regressors to control for this bias. ${ }^{11}$ The instrumental variable was spouse's age, which is thought to be related to spouse's political interest but not with the error term $u_{i m n}$.

\section{Results}

In Tables 3 and 4, estimation results of all samples are reported in columns (1) and (4). Results of sub-samples consisting of progressive and conservative males are in columns (2) and (5), and (3) and (6), respectively. Table 3 shows the results of the Probit

11 The Probit model with endogenous regressors uses instruments for endogenous variables. The software used for the estimation was Stata 10. 
estimations. Table 4 displays the Probit model and Probit model with endogenous regressors in columns (1)-(3) and (4)-(6), respectively.

Table 3 displays results of Spouse dummy and its interaction term with Interest in politics dummy. In the first row, Spouse Dummy produced both negative and positive signs, while being statistically insignificant. I found it interesting that a male's political view about women's empowerment was not dependent on having a spouse. Regarding the spouse's political interest effect, it can be seen from (Spouse dummy)* (interest in politics dummy) in columns (4)-(6) that positive signs were produced in all estimations, congruent with anticipated results. (Spouse dummy)* (interest in politics dummy) was statistically significant, as seen in column (4), indicating that spouse's political interest increased the likelihood that males considered women's empowerment important. After splitting the sample, results for conservative males in column (6) were statistically significant, but results for progressive males in column (5) were not significant. Furthermore, the value for conservative males was approximately 3.5 times larger than that for progressive males. Hence, it can be argued that a spouse's political interest has a greater influence on a conservative male's political view about women's empowerment.

Table 4 reveals that Interest in politics dummy was statistically significant in columns (1) and (3). The value for conservative males was about 3 times larger than that for progressive males, consistent with results shown in Table 3. Additionally, results were considered after controlling for endogeneity bias caused by a male's choice of spouse. As exhibited in column (4), Interest in politics dummy takes the anticipated positive sign, despite being statistically insignificant. It is surprising to observe that Interest in politics dummy produced an unexpected negative sign in column (5) and the anticipated sign in column (6). Results in column (5) are statistically insignificant, and column (6) exhibits results statistically significant at the $1 \%$ level. Furthermore, the value for conservative males, 2.27, is approximately 5 times larger than the 0.45 value in column (3). This indicates that a male's political preference is strongly associated with choice of spouse, resulting in estimation bias. As a consequence of controlling for this bias, a spouse's political interest increased conservative male support for women's empowerment, but did not influence support in progressive males.

Considering the statistical analysis based on the individual data as a whole, in general, a male's political view was affected by his spouse's characteristics, in particular her political interest. This effect was, however, remarkable for conservative males but not for progressive males. That is, the conservative male's view about a women's issue changed significantly with respect to his spouse's political interest, whereas the progressive male's view changed little. An example of a conservative male changing his 
views based on female family influence is represented by the legislation introduced by U.S. Senator Pete W. Domenici related to mental health benefits (Washington, 2008). ${ }^{12}$

\section{Conclusion}

A number of research studies have explored how individuals are affected by family structure and gender differences among family members. However, the relationship between an individual's interest in politics and political positions among family members has not been adequately considered in these studies. Therefore, this paper explored how the degree of a spouse's political interest affects the male's view about a women's issue, using individual level data compiled by the JEDS survey.

Key findings are as follows: (1) The degree of a spouse's political interest plays a role in whether males consider women's empowerment important. (2) This spouse effect is observed for conservative males but not for progressive males. (3) These results are unchanged when the endogeneity bias caused by spouse's political interest is controlled for. Based on these results, it is argued that interaction of political preferences among family members plays a critical role in determining views regarding gender issues.

Compared with the existing literature, the primary contribution of this paper is twofold. First, the present study provides an understanding of the effect of family structure on an individual's political view. Second, it elucidates the interaction effect of individuals and their family members' political preferences. This paper, however, did not explore various political and economic issues; other issues should be researched to ascertain the validity of the arguments in this paper. In addition, this paper did not present a theoretical framework on which to base results. Finally, the sample size was small in this study, and larger samples are recommended in future studies.

12 According to Washington (2008), by the early 1980s, Domenici had supported typical conservative policies. After his daughter was diagnosed with atypical schizophrenia, he changed his political views and became Congress's leading advocate for health insurance parity for mental illness. 


\section{References}

Abrams, B.A., \& Settle, R.F. (1998).Women's suffrage and the growth of the welfare state. Public Choice, 100, 289-300.

Aidt, T.S., \& Dallal, B. (2008).Female voting power: the contribution of women's suffrage to the growth of social spending in Western Europe (1869-1960). Public Choice, 134, 391-417.

Bertrand, M., Luttemer, E.F.P., \& Mullainathan, S. (2000). Network effects and welfare cultures. Quarterly Journal of Economics, 115, 1019-1055.

Breyer, F., \& v.d.Schulenburg, J.M.G. (1990).Family ties and social security in a democracy. Public Choice, 67, 155-167.

Cebula, R.J., \& Meads, H. (2008). An inquiry into the contemporary differential between female and male voter turnouts. Atlantic Economic Journal, 36, 301-313.

Edlund, L.C., \& Pande, R. (2002).Why have women become left-wing? The political gender gap and the decline in marriage. Quarterly Journal of Economics, 117, 917-961.

Fernandez, R., Fogli, A., \& Olivetti, C. (2004). Mother's and sons: Preference formation and female labor force dynamics. Quarterly Journal of Economics, 119, 1249-1299.

Funk, P. \& Gathmann, C. (2008). Gender gaps in policy making: Evidence from direct democracy in Switzerland. Economic Working Papers 1123, Department of Economics and Business, Universitat Pompeu Febra.

Goldin, C. (1990). Understanding the gender gap: an economic history of American women. Cambridge: Cambridge University Press.

Kawaguchi, D. \& Miyazaki, J. (2009). Working mothers and sons' preferences regarding female labor supply: Direct evidence from stated preferences. Journal of Population Economics, 22, 115-130.

Lott, L.R., \& Kenny, L.W. (1999). Did Women's suffrage change the size and scope of government? Journal of Political Economy, 107, 1163-1198.

Miller, G. (2008). Women's suffrage, political responsiveness, and child survival in American history. Quarterly Journal of Economics, 123, 1287-1327.

Sacerdote, B. (2007). How large are the effects from changes in family environment? A study of Korean American adoptees. Quarterly Journal of Economics, 122, 119-157.

Washington, E.L. (2008). Female socialization: How daughters affect their legislator father's voting on women's issues. American Economic Review, 98, 311-332. 
Warner, R. L. (1991). Does the sex of your child matter? Support for feminism among women and men in the United States and Canada. Journal of marriage and the Family, 53, 1051-1056.

Warner, R. L. \& Steel B.S. (1999).Child rearing as a mechanism for social change: The relationship of child gender to parents' commitment to gender equity. Gender and Society, 13, 503-517.

Wolfinger, R.E., \& Rosenstone, S.J. (1980). Who votes? New Haven; Yale University Press. 


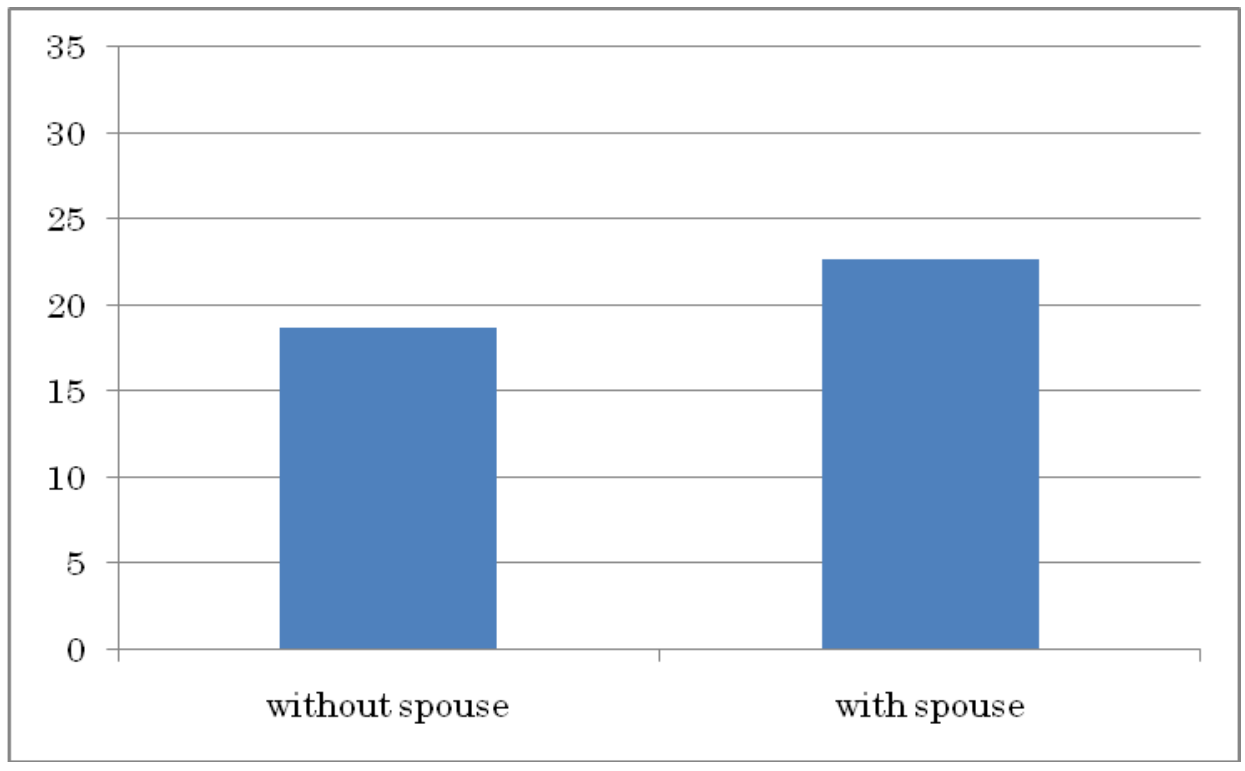

(a) Percentage of males without and with spouses.

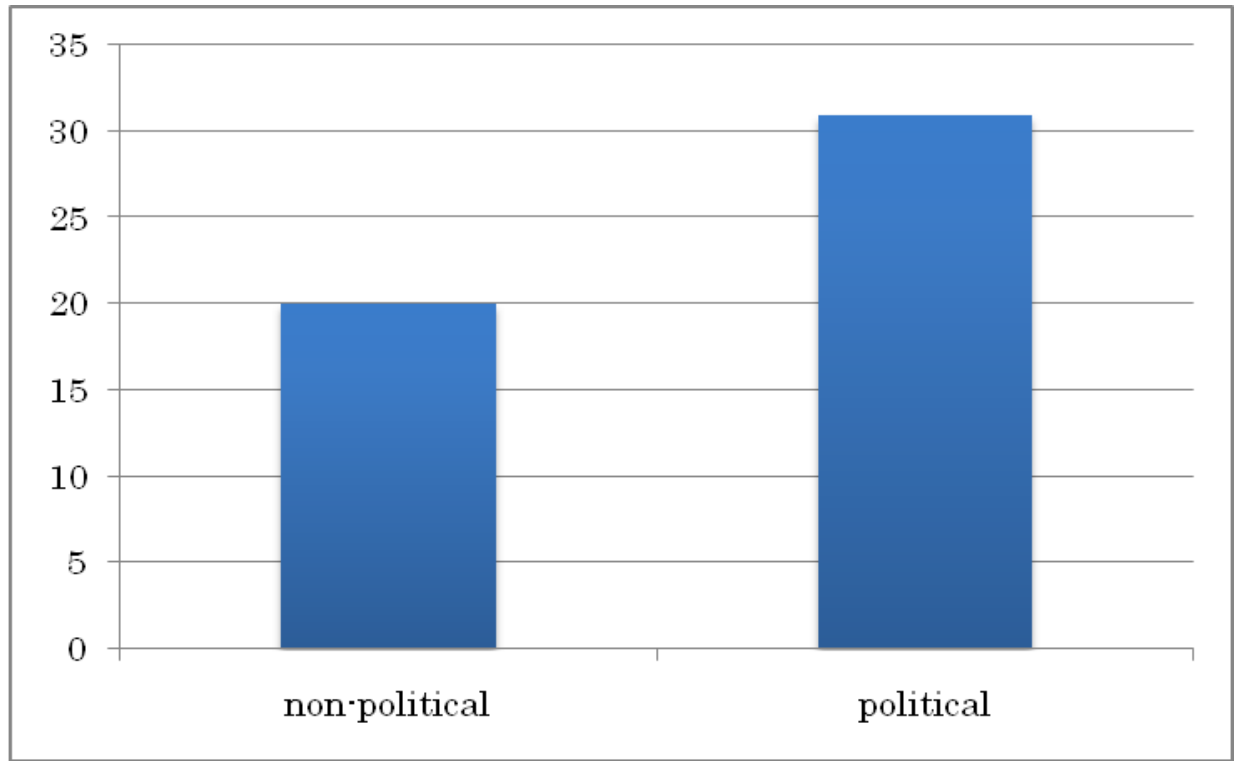

(b) Percentage of males' spouses interested in politics.

Fig.1 Percentage of males who thought women empowerment was important.

Note. Panel (b) limits sample to males with spouses. 
Table 1. Sample Construction (Numbers in samples)

\begin{tabular}{|c|c|c|}
\hline & ALL & $\begin{array}{l}\text { Males with spouses whose } \\
\text { ages were available }\end{array}$ \\
\hline Original Sample & 1618 & 746 \\
\hline Males & 749 & 640 \\
\hline $\begin{array}{l}\text { Views about women's empowerment and respondent } \\
\text { characteristics available. a }\end{array}$ & 478 (I) b & 472 \\
\hline Spouse's interest in politics available & 432 (I) b & 428 (II) d \\
\hline Male's political position available & $419 \quad(\mathrm{I}) \mathrm{b,c}$ & $415 \quad$ (II) d \\
\hline Male's political position progressive & $239 \quad(\mathrm{I}) \mathrm{b}, \mathrm{c}$ & $235 \quad(\mathrm{II}) \mathrm{d}$ \\
\hline Male's political position conservative & 180 (I) b,c & 180 (II) d \\
\hline
\end{tabular}

Note.

a. Individual characteristics included male's age, household income, education, and marital status. In addition, spouse was female.

b. (I) Sample was used for the estimation reported in Table 3.

c. (I) Sample was used in Table 2.

d. (II) Sample was used for the estimation reported in Table 4. 
Table 2. Comparison Between Progressive and Conservative Males

\begin{tabular}{lcc}
\hline & progressive & conservative \\
\hline $\begin{array}{l}\text { Percentage who thought women } \\
\text { empowerment important }\end{array}$ & 24.4 & 18.5 \\
$\begin{array}{l}\text { Percentage of spouses interested } \\
\text { in politics }\end{array}$ & 22.5 & 21.3 \\
Average age & 51.5 & 57.5 \\
$\begin{array}{l}\text { Average household income } \\
\text { (millions of yen) }\end{array}$ & 612 & 657 \\
$\begin{array}{l}\text { Average years of education } \\
\text { Pve }\end{array}$ & 12.2 & 11.7 \\
\hline
\end{tabular}


Table 3. Probit Model Estimations

\begin{tabular}{lllllll}
\hline & \multicolumn{1}{c}{$\begin{array}{c}(1) \\
\text { All }\end{array}$} & \multicolumn{1}{c}{$\begin{array}{c}(2) \\
\text { Progressive }\end{array}$} & $\begin{array}{c}\text { Conservative } \\
\text { All }\end{array}$ & \multicolumn{1}{c}{$\begin{array}{c}(5) \\
\text { Progressive }\end{array}$} & $\begin{array}{c}\text { (6) } \\
\text { Conservative }\end{array}$ \\
\hline Spouse dummy & -0.03 & -0.16 & 0.11 & 0.12 & 0.26 & 0.15 \\
& $(-0.14)$ & $(-0.48)$ & $(0.21)$ & $(0.45)$ & $(0.67)$ & $(0.27)$ \\
Spouse dummy* & & & & $0.28^{*}$ & 0.15 & $0.54^{*}$ \\
Interest in politics dummy & & & & $(1.72)$ & $(0.67)$ & $(1.97)$ \\
Ln (age) & 0.07 & -0.07 & 0.98 & 0.08 & -0.03 & 0.90 \\
& $(0.29)$ & $(-0.02)$ & $(1.50)$ & $(0.30)$ & $(-0.10)$ & $(1.34)$ \\
Ln (household income) & 0.11 & 0.12 & $0.53^{*}$ & 0.18 & 0.20 & $0.62^{*}$ \\
& $(0.91)$ & $(0.76)$ & $(1.95)$ & $(1.34)$ & $(1.10)$ & $(2.15)$ \\
Ln (years of education) & -0.17 & -0.64 & -0.06 & -0.19 & $-0.71^{*}$ & -0.06 \\
& $(-0.59)$ & $(-1.58)$ & $(-0.12)$ & $(-0.62)$ & $(-1.69)$ & $(-0.12)$ \\
\hline Obs & 478 & 262 & 194 & 432 & 239 & 180 \\
Wald chi-square & 17.8 & 17.4 & 28.4 & 23.5 & 18.2 & 33.4 \\
\hline
\end{tabular}

Note. a. Values are marginal effects. Values in parentheses are z-statistics calculated by robust standard errors. * and ${ }^{* *}$ denote significance at the $5 \%$ and $1 \%$ levels, respectively. In all estimations, constant, city size and area dummies are included, but not reported.

b. Women empowerment dummy was the dependent variable. 
Table 4 Probit Model and IV Probit Model

\begin{tabular}{|c|c|c|c|c|c|c|}
\hline & $\begin{array}{l}(1) \\
\text { All }\end{array}$ & $\begin{array}{c}(2) \\
\text { Progressive }\end{array}$ & $\begin{array}{c}\text { (3) } \\
\text { Conservative }\end{array}$ & $\begin{array}{l}(4) \# \\
\text { All }\end{array}$ & $\begin{array}{c}(5) \# \\
\text { Progressive }\end{array}$ & $\begin{array}{c}\text { (6) \# } \\
\text { Conservative }\end{array}$ \\
\hline Interest in politics & $0.28^{*}$ & 0.16 & $0.45^{*}$ & 1.20 & -1.81 & $2.27 * *$ \\
\hline dummy & $(1.79)$ & $(0.75)$ & $(1.72)$ & $(0.54)$ & $(-0.79)$ & $(2.66)$ \\
\hline Ln (age) & 0.15 & 0.04 & $1.07^{*}$ & 0.04 & 0.54 & $1.05^{*}$ \\
\hline & $(0.56)$ & $(0.13)$ & $(1.66)$ & $(0.12)$ & $(0.95)$ & $(1.87)$ \\
\hline (household & $0.25^{*}$ & 0.29 & $0.62^{*}$ & 0.22 & 0.27 & 0.51 \\
\hline income) & $(1.82)$ & $(1.60)$ & $(2.14)$ & $(1.30)$ & $(1.16)$ & $(1.64)$ \\
\hline Ln $\quad$ (years & -0.27 & $-0.88^{*}$ & -0.01 & -0.34 & -0.21 & 0.16 \\
\hline education)) & $(-0.86)$ & $(-2.03)$ & $(-0.03)$ & $(-1.08)$ & $(-0.16)$ & $(0.36)$ \\
\hline Obs & 428 & 235 & 180 & 428 & 235 & 180 \\
\hline Wald chi-square & 24.6 & 19.7 & 29.4 & 31.3 & 57.8 & 117.1 \\
\hline
\end{tabular}

Note. a. Samples were limited to males with a spouse. Values are marginal effects. Values in parentheses are z-statistics calculated by robust standard errors. * and ${ }^{* *}$ denote significance at the $5 \%$ and $1 \%$ levels, respectively. In all estimations, constant, city size and area dummies are included, but not reported. Interest in politics dummy was treated as an endogenous variables and thus instrumented (\# indicates IV probit model was employed). Age of spouse was used as an instrumental variable.

b. Women empowerment dummy was the dependent variable. 